\title{
Quantitative Assessment of Water Contaminants in the Rupsha River of Khulna Region for Irrigation Usage
}

\author{
M. K. Hossain, M. M. Rahman* and S. Hoque \\ Department of Agricultural Chemistry, Bangladesh Agricultural University, Mymensingh-2202 \\ "Corresponding author: mmr@bau.edu.bd
}

\begin{abstract}
Water samples were collected from the Rupsha river of Khulna region to determine ionic contamination for irrigation purpose. The chemical analyses included $\mathrm{pH}, \mathrm{EC}$, TDS and ions. $\mathrm{pH}$ values of water samples were slightly alkaline in nature. Samples were rated as fresh water based on TDS values. Samples were high salinity and low alkalinity hazards expressing C3S1. Regarding SAR and SSP values, samples were excellent and good classes, respectively. Samples were free from RSC and were very hard class. Regarding PI values, samples were under class-II implying 75\% maximum soil permeability. $\mathrm{Ca}, \mathrm{Mg}, \mathrm{Na}, \mathrm{Cu}, \mathrm{Ni}, \mathrm{Zn}, \mathrm{HCO}_{3}, \mathrm{SO}_{4}$ and $\mathrm{PO}_{4}$ levels in samples were within safe limit. $\mathrm{Cd}$, $\mathrm{Cr}$ and $\mathrm{Cl}$ ions in water samples were above the permissible limit and were treated as water contaminants for irrigation. From the present findings, it is noted that the detected ions as water contaminants should be considered for irrigation usage toward food safety.
\end{abstract}

Key words: Food safety, Irrigation, Rupsha River, Water contaminants

\section{Introduction}

Rivers are the most important natural water sources used for irrigation but in the developing countries, water is the most poorly managed resources (Islam et al., 2015; Ahmed et al., 2016). River plays an important role in carrying or assimilation of the industrial and municipal wastes and runoff from agricultural fields. Recently water bodies are being used arbitrarily as dumps and water pollution has become dreadful (Samad et al., 2015). Due to the unplanned rapid industrialization, heavy metal contamination has become a serious environmental problem in aquatic environment. The increasing heavy metal pollution have a significant adverse health effects for invertebrates, fish and humans as well as for plants (Yi et al., 2011; Islam et al., 2014; Ahmed et al., 2015; Ali et al., 2016). Daily about 0.4 millions $\mathrm{m}^{3}$ of untreated industrial waste is being discharged into urban river water in Bangladesh (Arefin et al., 2016). The chemical components of irrigation water can create plant toxicity or deficiency directly, or can affect plants by altering availability of nutrients (Uddin et al., 2014). Irrigation water quality is related to its management and effects on soils and crops. Vegetables and rice may be contaminated with heavy metals and possess a potential health risk if it is grown in contaminated soils (Arefin et al., 2016). For this reason, it is very important to monitor the levels of ionic contamination of its rivers regularly.

Khulna city is situated in the South-West division of Bangladesh. It is the third largest industrial city after the position of Dhaka and Chittagong city. A lot of industries have been built up near the Rupsha river and this region is the most pollution hotspot by the department of environment in Bangladesh. The polluting industries of Khulna region such as chemical complexes, fish processing plants, steel mills, paper mills, rayon mill complexes, cement factories, paint and dye manufacturing plants are directly discharging their untreated toxic effluent into the Rupsha river system. This waste water is ultimately carried out to the Sundarbans through the Rupsha river system (Samad et al., 2015). During the dry season, crop fields are irrigated continuously with contaminated water situated adjacent to the Rupsha river (FAO, 2011; Islam et al., 2016). Due to the availability and cost effectiveness of surface water, this river water is usually applied as a prime source of irrigation purpose by the farmers. Knowledge of river water quality principles helps to determine the potential of water body for irrigation. So, water analysis is usually necessary for measuring the level of ionic contamination in water, which meets standards for irrigating agricultural crops. Keeping these above facts in mind, this study was performed to evaluate the degree of ionic contamination present in the Rupsha river water used for irrigation.

\section{Water sampling site}

\section{Materials and Methods}

In Khulna region, the Rupsha river was selected on the basis of intensity of water contamination caused by discharge of untreated industrial effluents. Twenty water samples were collected from crop fields irrigated with the contaminated water of the Rupsha river. The 
exact location of each sampling point was determined using GPS. Accordingly, the entire sampling sites was confined between the longitude 89 34 '28.5"and $89^{\circ} 35^{\prime} 15.8^{\prime \prime}$ East and the latitude $22^{\circ} 466^{\prime} 56.8^{\prime \prime}$ and $22^{\circ} 49$ '57.7" North. The sampling locations have been shown in Table 1. The detailed sampling sites have been presented in Fig. 1. This sampling was carried out in the month of January, 2017.

Table 1. Sampling locations in the Rupsha River

\begin{tabular}{cll|ccc}
\hline $\begin{array}{c}\text { Sample ID } \\
\text { No. }\end{array}$ & Latitude (N) & Longitude (E) & $\begin{array}{c}\text { Sample } \\
\text { ID No. }\end{array}$ & Latitude (N) & Longitude (E) \\
\hline 1 & $22^{\circ} 49^{\prime} 57.7^{\prime \prime}$ & $89^{\circ} 34^{\prime} 28.5^{\prime \prime}$ & 11 & $22^{\circ} 48^{\prime} 42.8^{\prime \prime}$ & $89^{\circ} 35^{\prime} 08.3^{\prime \prime}$ \\
2 & $22^{\circ} 49^{\prime} 54.9^{\prime \prime}$ & $89^{\circ} 34^{\prime} 35.3^{\prime \prime}$ & 12 & $22^{\circ} 48^{\prime} 26.2^{\prime \prime}$ & $89^{\circ} 35^{\prime} 09.4^{\prime \prime}$ \\
3 & $22^{\circ} 49^{\prime} 46.0^{\prime \prime}$ & $89^{\circ} 34^{\prime} 45.7^{\prime \prime}$ & 13 & $22^{\circ} 48^{\prime} 12.4^{\prime \prime}$ & $89^{\circ} 35^{\prime} 11.2^{\prime \prime}$ \\
4 & $22^{\circ} 49^{\prime} 39.1^{\prime \prime}$ & $89^{\circ} 34^{\prime} 52.3^{\prime \prime}$ & 14 & $22^{\circ} 47^{\prime} 59.0^{\prime \prime}$ & $89^{\circ} 35^{\prime} 14.0^{\prime \prime}$ \\
5 & $22^{\circ} 49^{\prime} 35.9^{\prime \prime}$ & $89^{\circ} 34^{\prime} 57.3^{\prime \prime}$ & 15 & $22^{\circ} 47^{\prime} 47.7^{\prime \prime}$ & $89^{\circ} 35^{\prime} 15.8^{\prime \prime}$ \\
6 & $22^{\circ} 49^{\prime} 27.3^{\prime \prime}$ & $89^{\circ} 35^{\prime} 01.1^{\prime \prime}$ & 16 & $22^{\circ} 47^{\prime} 40.6^{\prime \prime}$ & $89^{\circ} 35^{\prime} 13.5^{\prime \prime}$ \\
7 & $22^{\circ} 49^{\prime} 19.6^{\prime \prime}$ & $89^{\circ} 35^{\prime} 03.7^{\prime \prime}$ & 17 & $22^{\circ} 47^{\prime} 26.7^{\prime \prime}$ & $89^{\circ} 35^{\prime} 03^{\prime \prime}$ \\
8 & $22^{\circ} 49^{\prime} 11.5^{\prime \prime}$ & $89^{\circ} 35^{\prime} 07.1^{\prime \prime}$ & 18 & $22^{\circ} 47^{\prime} 17.0^{\prime \prime}$ & $89^{\circ} 35^{\prime} 05.2^{\prime \prime}$ \\
9 & $22^{\circ} 48^{\prime} 58.3^{\prime \prime}$ & $89^{\circ} 35^{\prime} 07.6^{\prime \prime}$ & 19 & $22^{\circ} 47^{\prime} 06.7^{\prime \prime}$ & $89^{\circ} 35^{\prime} 03.0^{\prime \prime}$ \\
10 & $22^{\circ} 48^{\prime} 50.1^{\prime \prime}$ & $89^{\circ} 35^{\prime} 06.9^{\prime \prime}$ & 20 & $22^{\circ} 46^{\prime} 56.8^{\prime \prime}$ & $89^{\circ} 35^{\prime} 02.3^{\prime \prime}$ \\
\hline
\end{tabular}

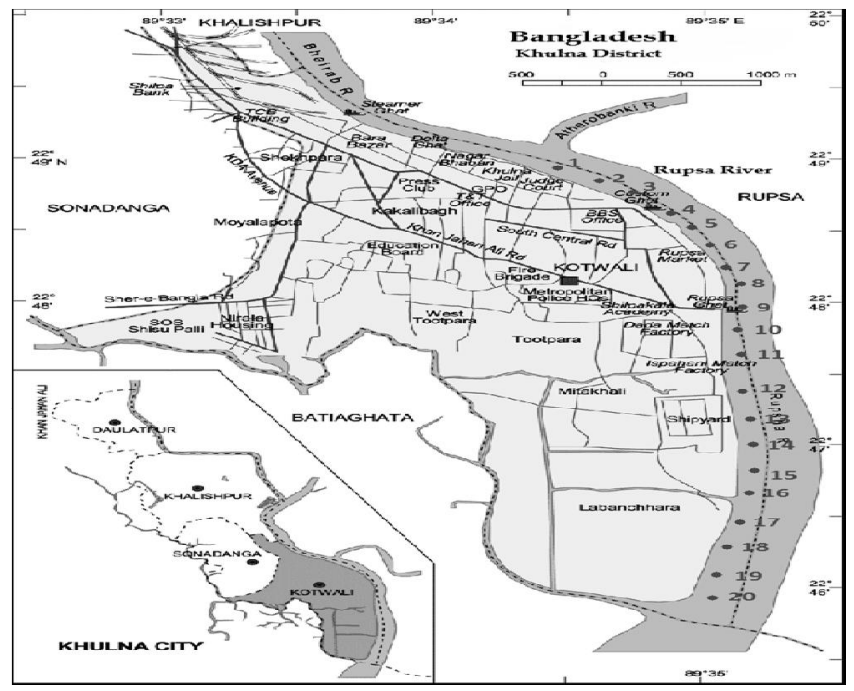

Fig. 1. Geographic location of the study areas in the Rupsha River

\section{Water sampling technique}

Water samples were collected from $0.50 \mathrm{~m}$ below water surface maintaining a reasonable distance from the river bank. Water samples were collected from each location in $500 \mathrm{~mL}$ plastic bottles. Each bottle were previously cleaned with dilute $\mathrm{HCl}(1: 1)$ and then washed with distilled water. All bottles were rinsed 3 to 4 times before sampling with water to be sampled. For metal analysis, the collected water samples were acidified $(\mathrm{pH}<2)$ with $\mathrm{HNO}_{3}$ to prevent the loss of metal following the sampling technique of APHA (2012). All plastic bottles were sealed tightly and transferred to the Postgraduate Research Laboratory, Department of Agricultural Chemistry, Bangladesh Agricultural University, Mymensingh for chemical analysis. The samples were kept in a clean, cool and dry place. River water samples were filtered through filter papers (Whatman No. 1 and 42) to remove undesirable solids and suspended materials before commencing the chemical analysis.

\section{Water analysis}

$\mathrm{pH}$, electrical conductivity (EC) and total dissolved solids (TDS) values of water samples were measured electrometrically as outlined by Gupta (2013). The concentrations of $\mathrm{Ca}$ and $\mathrm{Mg}$ ions in water samples were estimated by EDTA titrimetric method (Tandon, 2013). The contents of $\mathrm{K}$ and $\mathrm{Na}$ ions in samples were determined by flame photometric method while the levels of $\mathrm{Cd}, \mathrm{Cr}, \mathrm{Cu}, \mathrm{Ni}$ and $\mathrm{Zn}$ ions in water samples were analyzed directly by atomic absorption spectrometric method as described by APHA (2012). Titrimetric methods were used to determine the amounts of $\mathrm{Cl}, \mathrm{CO}_{3}$ and $\mathrm{HCO}_{3}$ ions from water samples (Gupta et al., 2012; Tandon, 2013). The concentration of $\mathrm{PO}_{4}$ ion in river water samples was determined by spectrophotometric method (APHA, 
2012) and $\mathrm{SO}_{4}$ ion content in samples was determined by turbidimertic method (Tandon, 2013).

\section{Ionic contamination rating}

The following chemical quality factors were considered in assessing major ionic contamination of water samples by the interpretation of analytical result:

i) Sodium adsorption ratio (SAR)

$$
\mathrm{SAR}=\frac{\mathrm{Na}^{+}}{\sqrt{\frac{\mathrm{Ca}^{2+}+\mathrm{Mg}^{2+}}{2}}}
$$

ii) Soluble sodium percentage (SSP)

$$
\mathrm{SSP}=\frac{\mathrm{Na}^{+}+\mathrm{K}^{+}}{\mathrm{Ca}^{2+}+\mathrm{Mg}^{2+}+\mathrm{Na}^{+}+\mathrm{K}^{+}} \times 100
$$

iii) Residual sodium carbonate ( $\mathrm{RSC})$

$$
\mathrm{RSC}=\left(\mathrm{CO}_{3}{ }^{2-}+\mathrm{HCO}_{3}^{-}\right) \ddot{i}\left(\mathrm{Ca}^{2+}+\mathrm{Mg}^{2+}\right)
$$

iv) Hardness $\left(\mathrm{H}_{\mathrm{T}}\right)$

$$
\mathrm{H}_{\mathrm{T}}=2.5 \times \mathrm{Ca}^{2+}+4.1 \times \mathrm{Mg}^{2+}
$$

v) Permeability index (PI)

$$
\mathrm{PI}=\left[\left(\mathrm{Na}^{+}+\widetilde{\mathrm{aHCO}_{3}}{ }^{-}\right) /\left(\mathrm{Ca}^{2+}+\mathrm{Mg}^{2+}+\mathrm{Na}^{+}\right)\right] \times 100
$$

Whereas, all ionic concentrations were expressed as me $\mathrm{L}^{-1}$ but in case of hardness, cationic concentrations were expressed as $\mathrm{mg} \mathrm{L}^{-1}$.

\section{Statistical analysis}

According to Gomez and Gomez (1984), statistical analyses of analytical results obtained from river water samples were performed. Excel and Minitab computer programs were used for correlation studies.

\section{pH, EC and TDS}

\section{Results and Discussion}

$\mathrm{pH}$ value of the collected water samples from Rupsha river fluctuated from 7.34 to 7.56 indicating slightly alkaline in nature (Table 2). According to FAO (1992), the recommended $\mathrm{pH}$ range for irrigation water is from 6.5 to 8.4. All the samples did not exceed the acceptable range and were not problematic for longterm irrigation. Electrical conductivity (EC) values of all the collected water samples were within the limit of 899.0 to $1409.0 \mu \mathrm{S} \mathrm{cm}^{-1}$ with an average value of $1262.4 \mu \mathrm{S} \mathrm{cm}^{-1}$ (Table 2). According to Wallender and Tanji (2011), all the samples under test were rated in C3 category ( $\mathrm{EC}=750.0-2250.0 \mathrm{\varepsilon S} \mathrm{cm}^{-1}$ ) indicating high salinity. High salinity water was treated as unsuitable for irrigation purpose and could not be safely used for sensitive crops. Total dissolved solids (TDS) values of water samples were within the range of 600.0 to $940.0 \mathrm{mg} \mathrm{L}^{-1}$ having a mean value of 841.5 $\mathrm{mg} \mathrm{L}^{-1}$ (Table 2). According to Freeze and Cherry

\begin{tabular}{|c|c|c|c|c|c|c|c|}
\hline $\begin{array}{l}\text { Sample } \\
\text { ID No. }\end{array}$ & $\mathrm{pH}$ & $\begin{array}{c}\mathrm{EC} \\
\left(\mu \mathrm{S} \mathrm{cm}^{-1}\right)\end{array}$ & $\begin{array}{l}\text { TDS } \\
\text { é ..é }\end{array}$ & \multicolumn{2}{|c|}{$\frac{\mathrm{PO}_{4}}{\mathrm{mg} \mathrm{L}^{-1} \text { é é é é é é é } . .}$} & \multicolumn{2}{|c|}{$\begin{array}{cc}\mathrm{Cl} & \mathrm{HCO}_{3} \\
\text { é é é . me L }{ }^{-1} \text { é é é é }\end{array}$} \\
\hline 1 & 7.34 & 899.0 & 600.0 & 1.47 & 4.90 & 16.00 & 0.09 \\
\hline 2 & 7.56 & 1159.0 & 770.0 & 0.66 & 5.87 & 18.71 & 0.05 \\
\hline 3 & 7.41 & 1121.0 & 737.5 & 0.50 & 6.35 & 18.99 & 0.07 \\
\hline 4 & 7.55 & 1219.0 & 815.0 & 0.91 & 6.49 & 19.14 & 0.06 \\
\hline 5 & 7.52 & 1160.0 & 775.0 & 0.53 & 6.63 & 19.99 & 0.07 \\
\hline 6 & 7.49 & 1362.0 & 915.0 & 0.31 & 6.73 & 21.14 & 0.06 \\
\hline 7 & 7.37 & 1279.0 & 855.0 & 0.72 & 7.07 & 20.99 & 0.06 \\
\hline 8 & 7.54 & 1292.0 & 862.5 & 0.53 & 6.78 & 20.71 & 0.05 \\
\hline 9 & 7.53 & 1250.0 & 835.0 & 0.34 & 6.11 & 21.28 & 0.06 \\
\hline 10 & 7.45 & 1275.0 & 852.5 & 0.97 & 7.36 & 20.99 & 0.06 \\
\hline 11 & 7.41 & 1230.0 & 800.0 & 0.34 & 9.23 & 21.42 & 0.06 \\
\hline 12 & 7.54 & 1388.0 & 927.5 & 0.50 & 8.99 & 24.99 & 0.06 \\
\hline 13 & 7.53 & 1394.0 & 935.0 & 1.31 & 8.51 & 24.28 & 0.06 \\
\hline 14 & 7.38 & 1399.0 & 937.5 & 0.41 & 8.32 & 23.85 & 0.06 \\
\hline 15 & 7.53 & 1397.0 & 932.5 & 1.31 & 7.84 & 19.57 & 0.05 \\
\hline 16 & 7.52 & 1409.0 & 940.0 & 0.41 & 7.93 & 22.85 & 0.05 \\
\hline 17 & 7.43 & 1215.0 & 807.5 & 0.75 & 7.55 & 20.42 & 0.06 \\
\hline 18 & 7.52 & 1254.0 & 837.5 & 0.44 & 6.54 & 20.57 & 0.07 \\
\hline 19 & 7.55 & 1316.0 & 877.5 & 0.38 & 6.73 & 19.99 & 0.07 \\
\hline 20 & 7.47 & 1229.0 & 817.5 & 0.25 & 6.97 & 20.57 & 0.07 \\
\hline Min. & 7.34 & 899.0 & 600.0 & 0.25 & 4.90 & 16.00 & 0.05 \\
\hline Max. & 7.56 & 1409.0 & 940.0 & 1.47 & 9.23 & 24.99 & 0.09 \\
\hline Mean & - & 1262.4 & 841.5 & 0.65 & 7.15 & 20.82 & 0.06 \\
\hline SD & - & 122.5 & 83.8 & 0.36 & 1.08 & 2.06 & 0.01 \\
\hline $\mathrm{CV}(\%)$ & - & 9.7 & 9.9 & 55.66 & 15.14 & 9.88 & 15.35 \\
\hline $\begin{array}{l}{ }^{\mathrm{a}} \mathrm{FAO} \\
\text { value }\end{array}$ & $6.5-8.4$ & - & - & 2.00 & 20.00 & 4.00 & 1.50 \\
\hline
\end{tabular}
(1979), all the samples were classified as fresh water (TDS $<1,000 \mathrm{mg} \mathrm{L}^{-1}$ ) in quality. These water samples would not affect soil properties and plant growth as irrigation water.

Table 2. pH, EC, TDS and anionic constituents of river water samples

${ }^{a} \mathrm{FAO}$ (1992) 
$\mathrm{PO}_{4}, \mathrm{SO}_{4}, \mathrm{Cl}, \mathrm{HCO}_{3}$ and $\mathrm{CO}_{3}$ levels

The levels of $\mathrm{PO}_{4}$ and $\mathrm{SO}_{4}$ in the collected water samples varied from 0.25 to 1.47 and 4.90 to $9.23 \mathrm{mg}$ $\mathrm{L}^{-1}$ having mean values of 0.65 and $7.15 \mathrm{mg} \mathrm{L}^{-1}$, respectively (Table 2 ). The maximum permissible limits of $\mathrm{PO}_{4}$ and $\mathrm{SO}_{4}$ ions in irrigation water are 2.00 and $20.00 \mathrm{mg} \mathrm{L}^{-1}$, respectively (FAO, 1992). As per this limit, all the water samples were suitable for irrigation having no hazard effects on soil properties and crop growth in the study area. Water samples collected from the Rupsha River contained $\mathrm{Cl}$ ion within the limit of 16.00 to $24.99 \mathrm{me} \mathrm{L}^{-1}$ with an average value of $20.82 \mathrm{me} \mathrm{L}^{-1}$ (Table 2). According to FAO (1992), maximum permissible limit of $\mathrm{Cl}$ in irrigation water is $4.00 \mathrm{me} \mathrm{L}^{-1}$. On the basis of this limit, all the water samples exceeded the permissible level and this anion was treated as water contaminant for irrigation usage. The concentration of $\mathrm{HCO}_{3}$ ion in the collected water samples fluctuated from 0.05 to $0.09 \mathrm{me} \mathrm{L}^{-1}$ with a mean value of $0.06 \mathrm{me} \mathrm{L}^{-1}$ (Table 2). According to FAO (1992), the recommended maximum concentration of $\mathrm{HCO}_{3}$ ion for irrigation water used continuously on soil is $1.5 \mathrm{me} \mathrm{L}^{-1}$. As per this acceptable range, $\mathrm{HCO}_{3}$ ionic status of all the collected river water samples was suitable for irrigation. The amount of $\mathrm{CO}_{3}$ ion was not detected in the collected water samples indicating that river water samples were free from $\mathrm{CO}_{3}$.

\section{Ca, Mg, K and Na levels}

The concentrations of $\mathrm{Ca}, \mathrm{Mg}, \mathrm{K}$ and $\mathrm{Na}$ ions in all the samples were found to vary from 2.96 to $3.60,3.28$ to $4.80,0.10$ to 0.16 and 2.33 to $3.23 \mathrm{me} \mathrm{L}^{-1}$ with average values of $3.22,4.02,0.12$ and $2.78 \mathrm{me} \mathrm{L}^{-1}$, respectively (Table 3). Water containing less than $20.0 \mathrm{me} \mathrm{L}^{-1} \mathrm{Ca}$, 5.0 me $\mathrm{L}^{-1} \mathrm{Mg}, 0.05 \mathrm{me} \mathrm{L}^{-1} \mathrm{~K}$ and $40.0 \mathrm{me} \mathrm{L}^{-1} \mathrm{Na}$ ions is suitable for irrigating agricultural crops (FAO, 1992). Considering the limits of these ions, all the water samples of the study area could safely be applied for long-term irrigation without any harmful effect on soil properties and crop growth. But in case of K status, all the collected river water samples might be problematic for irrigation.

Table 3. Cationic constituents of river water samples

\begin{tabular}{|c|c|c|c|c|c|c|c|c|c|}
\hline \multirow[b]{2}{*}{ Sample ID No. } & $\mathrm{Ca}$ & $\mathrm{Mg}$ & $\mathrm{K}$ & $\mathrm{Na}$ & $\mathrm{Cd}$ & $\mathrm{Cr}$ & $\mathrm{Cu}$ & $\mathrm{Zn}$ & $\mathrm{Ni}$ \\
\hline & \multicolumn{4}{|c|}{ é é é é é é é é é me $L^{-1}$ é é é é é é é é é } & \multicolumn{5}{|c|}{ é é é é é é é é é é $m L^{-1}$ é é é é é é é é é é é } \\
\hline 1 & 3.60 & 3.60 & 0.10 & 2.33 & 0.016 & BDL & BDL & BDL & BDL \\
\hline 2 & 2.96 & 3.60 & 0.12 & 2.55 & 0.028 & BDL & BDL & BDL & BDL \\
\hline 3 & 3.44 & 3.28 & 0.10 & 2.60 & 0.031 & BDL & BDL & BDL & BDL \\
\hline 4 & 3.20 & 3.52 & 0.13 & 2.86 & 0.022 & BDL & BDL & BDL & BDL \\
\hline 5 & 3.12 & 3.52 & 0.10 & 2.60 & 0.024 & BDL & BDL & BDL & BDL \\
\hline 6 & 3.28 & 3.84 & 0.11 & 2.73 & 0.023 & BDL & BDL & BDL & BDL \\
\hline 7 & 3.20 & 4.16 & 0.12 & 2.78 & 0.017 & BDL & BDL & BDL & BDL \\
\hline 8 & 3.28 & 3.84 & 0.13 & 2.78 & 0.025 & BDL & BDL & BDL & BDL \\
\hline 9 & 3.04 & 4.00 & 0.11 & 2.86 & 0.025 & BDL & BDL & BDL & BDL \\
\hline 10 & 2.96 & 4.08 & 0.14 & 2.81 & 0.030 & BDL & BDL & BDL & BDL \\
\hline 11 & 3.12 & 3.60 & 0.11 & 2.78 & 0.033 & BDL & BDL & BDL & BDL \\
\hline 12 & 3.20 & 4.64 & 0.14 & 3.23 & 0.028 & BDL & BDL & BDL & BDL \\
\hline 13 & 3.12 & 4.72 & 0.16 & 3.05 & 0.031 & BDL & BDL & BDL & BDL \\
\hline 14 & 3.04 & 4.80 & 0.13 & 3.02 & 0.035 & 0.09 & BDL & BDL & BDL \\
\hline 15 & 3.28 & 4.40 & 0.15 & 2.89 & 0.032 & 0.14 & BDL & BDL & BDL \\
\hline 16 & 3.36 & 4.16 & 0.13 & 2.86 & 0.027 & 0.30 & BDL & BDL & BDL \\
\hline 17 & 3.28 & 4.48 & 0.12 & 2.89 & 0.025 & 0.25 & BDL & BDL & BDL \\
\hline 18 & 3.36 & 3.92 & 0.11 & 2.63 & 0.031 & 0.05 & BDL & BDL & BDL \\
\hline 19 & 3.36 & 4.08 & 0.12 & 2.55 & 0.024 & 0.25 & BDL & BDL & BDL \\
\hline 20 & 3.28 & 4.08 & 0.12 & 2.71 & 0.023 & 0.18 & BDL & $\mathrm{BDL}$ & BDL \\
\hline Min. & 2.96 & 3.28 & 0.10 & 2.33 & 0.016 & 0.05 & - & - & - \\
\hline Max. & 3.60 & 4.80 & 0.16 & 3.23 & 0.035 & 0.30 & - & - & - \\
\hline Mean & 3.22 & 4.02 & 0.12 & 2.78 & 0.026 & 0.18 & - & - & - \\
\hline SD & 0.16 & 0.43 & 0.01 & 0.20 & 0.005 & 0.09 & - & - & - \\
\hline $\mathrm{CV}(\%)$ & 5.03 & 10.75 & 11.40 & 7.30 & 19.02 & 51.12 & - & - & - \\
\hline${ }^{\mathrm{a}} \mathrm{FAO}$ value & 20.00 & 5.00 & 0.05 & 40.00 & 0.01 & 0.10 & 0.20 & 2.00 & 0.20 \\
\hline
\end{tabular}

\section{Cd, Cu, Cr, Zn and Ni levels}

The concentration of $\mathrm{Cd}$ ion in water samples of Rupsha river varied from 0.016 to $0.035 \mathrm{mg} \mathrm{L}^{-1}$ with an average value of $0.026 \mathrm{mg} \mathrm{L}^{-1}$ (Table 3). According to FAO (1992), the permissible limit of Cd ion in water

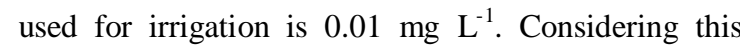
value as standard, all the water samples under investigation exceeded the acceptable limit and this metal ion was considered as water contaminant for long-term irrigation. Out of 20 samples, $\mathrm{Cr}$ ion content 
in only 7 water samples ranged from 0.05 to $0.30 \mathrm{mg}$ $\mathrm{L}^{-1}$ with a mean value of $0.18 \mathrm{mg} \mathrm{L}^{-1}$ (Table 3 ). According to FAO (1992), the permissible limit of $\mathrm{Cr}$ in irrigation water is $0.10 \mathrm{mg} \mathrm{L}^{-1}$. On the basis of this limit, only 5 water samples under investigation were hazardous for irrigation and the rest samples could safely be used for irrigation without harmful effect on soils and crops grown in the study area. These findings might be due to the disposal of untreated industrial waste containing $\mathrm{Cd}$ and $\mathrm{Cr}$ ions as water contaminants into the Rupsha river. All the water samples contained below detection limits of $\mathrm{Cu}, \mathrm{Zn}$ and $\mathrm{Ni}$ ions (Table 3 ). FAO (1992) recommended the respective concentrations of $\mathrm{Cu}, \mathrm{Zn}$ and $\mathrm{Ni}$ ions for irrigation are $0.20,2.0$ and $0.20 \mathrm{mg} \mathrm{L}^{-1}$. On the basis of these recommendation limits, all the collected samples would safely be used for irrigation purpose.

\section{SAR, SSP, RSC, Hardness and PI values}

The calculated SAR values of water samples ranged from 1.23 to 1.63 having an average value of 1.46 . (Table 4). Water used for irrigation having SAR less than 10 might not be harmful for agricultural crops (Todd and Mays, 2005). Considering this classification, all the samples were rated as low alkalinity hazard (S1) class reflecting excellent for irrigation. The computed SSP values in the collected water samples fluctuated from 25.26 to $30.63 \%$ with a mean value of $28.55 \%$ (Table 4 ). According to water classification proposed by Todd and Mays (2005), all the samples were classified as good (SSP=20-40\%). In the study area, water samples might be applied safely for irrigating agricultural crops. RSC values of the collected water sample from the study area ranged from -7.78 to -6.51 me $\mathrm{L}^{-1}$ with a mean value of -7.18 me $L^{-1}$ (Table 4). As per classification suggested by Schwartz and Zhang (2012), all the water samples were rated as suitable class $\left(\mathrm{RSC}<1.25 \mathrm{me}^{-1}\right)$. For this reason, all the river water samples might not be problematic for irrigation usage. The obtained results in Table 4 revealed that hardness $\left(\mathrm{H}_{\mathrm{T}}\right)$ values of the collected water samples varied from 327.67 to 391.51 $\mathrm{mg} \mathrm{L}^{-1}$ having a mean value of $361.62 \mathrm{mg} \mathrm{L}^{-1}$. Sawyer and McCarty (1967) suggested a classification for irrigation water based on hardness and according to this classification, all the samples were very hard $\left(\mathrm{H}_{\mathrm{T}}>300 \mathrm{mg} \mathrm{L}^{-1}\right)$ in quality. The computed PI values were found to vary from 27.55 to $32.42 \%$ having a mean value of $30.18 \%$ (Table 4). Doneen (1964) had prepared a chart to classify water based on its permeability index (PI). Regarding the obtained PI values, all the water samples were under class-II implying $75 \%$ of maximum permeability when applied to soil system as irrigation water.

Table 4. Chemical quality rating of river water samples and its suitability for irrigation

\begin{tabular}{|c|c|c|c|c|c|c|c|c|c|c|}
\hline \multirow{2}{*}{$\begin{array}{l}\text { Sample } \\
\text { ID No. }\end{array}$} & \multicolumn{2}{|c|}{ SAR } & \multicolumn{2}{|c|}{ SSP } & \multicolumn{2}{|c|}{ RSC } & \multicolumn{2}{|c|}{$\mathrm{H}^{5}$} & \multicolumn{2}{|c|}{ PI } \\
\hline & Ratio & Class & $\%$ & Class & $m e L^{-1}$ & Class & $\mathrm{mg} \mathrm{L}^{-1}$ & Class & $\%$ & Class \\
\hline 1 & 1.23 & Ex. & 25.26 & Good & -7.11 & Suit & 359.73 & $\mathrm{VH}$ & 27.55 & Class-II \\
\hline 2 & 1.41 & Ex. & 28.72 & Good & -6.51 & Suit & 327.67 & $\mathrm{VH}$ & 30.48 & Class-II \\
\hline 3 & 1.42 & Ex. & 28.66 & Good & -6.65 & Suit & 335.77 & $\mathrm{VH}$ & 30.77 & Class-II \\
\hline 4 & 1.56 & Ex. & 30.63 & Good & -6.66 & Suit & 335.70 & $\mathrm{VH}$ & 32.42 & Class-II \\
\hline 5 & 1.43 & Ex. & 28.93 & Good & -6.57 & Suit & 331.70 & $\mathrm{VH}$ & 30.9 & Class-II \\
\hline 6 & 1.45 & Ex. & 28.52 & Good & -7.06 & Suit & 355.66 & $\mathrm{VH}$ & 30.19 & Class-II \\
\hline 7 & 1.45 & Ex. & 28.25 & Good & -7.30 & Suit & 367.59 & $\mathrm{VH}$ & 29.84 & Class-II \\
\hline 8 & 1.48 & Ex. & 28.91 & Good & -7.07 & Suit & 355.66 & $\mathrm{VH}$ & 30.43 & Class-II \\
\hline 9 & 1.53 & Ex. & 29.72 & Good & -6.98 & Suit & 351.61 & $\mathrm{VH}$ & 31.37 & Class-II \\
\hline 10 & 1.5 & Ex. & 29.35 & Good & -6.98 & Suit & 351.58 & $\mathrm{VH}$ & 31.00 & Class-II \\
\hline 11 & 1.52 & Ex. & 30.14 & Good & -6.66 & Suit & 335.68 & $\mathrm{VH}$ & 31.85 & Class-II \\
\hline 12 & 1.63 & Ex. & 30.11 & Good & -7.78 & Suit & 391.51 & $\mathrm{VH}$ & 31.40 & Class-II \\
\hline 13 & 1.54 & Ex. & 28.9 & Good & -7.78 & Suit & 391.49 & $\mathrm{VH}$ & 30.23 & Class-II \\
\hline 14 & 1.53 & Ex. & 28.68 & Good & -7.78 & Suit & 391.47 & $\mathrm{VH}$ & 30.06 & Class-II \\
\hline 15 & 1.48 & Ex. & 28.24 & Good & -7.63 & Suit & 383.56 & $\mathrm{VH}$ & 29.51 & Class-II \\
\hline 16 & 1.48 & Ex. & 28.51 & Good & -7.47 & Suit & 375.61 & $\mathrm{VH}$ & 29.64 & Class-II \\
\hline 17 & 1.47 & Ex. & 27.97 & Good & -7.70 & Suit & 387.55 & $\mathrm{VH}$ & 29.42 & Class-II \\
\hline 18 & 1.38 & Ex. & 27.38 & Good & -7.21 & Suit & 363.65 & $\mathrm{VH}$ & 29.09 & Class-II \\
\hline 19 & 1.32 & Ex. & 26.4 & Good & -7.37 & Suit & 371.62 & $\mathrm{VH}$ & 28.06 & Class-II \\
\hline 20 & 1.41 & Ex. & 27.74 & Good & -7.29 & Suit & 367.62 & $\mathrm{VH}$ & 29.42 & Class-II \\
\hline Min. & 1.23 & - & 25.26 & - & -7.78 & - & 327.67 & - & 27.55 & - \\
\hline Max. & 1.63 & - & 30.63 & - & -6.51 & - & 391.51 & - & 32.42 & - \\
\hline Mean & 1.46 & - & 28.55 & - & -7.18 & - & 361.62 & - & 30.18 & - \\
\hline SD & 0.09 & - & 1.25 & - & 0.43 & - & 21.20 & - & 1.19 & - \\
\hline $\mathrm{CV}(\%)$ & 6.04 & - & 4.38 & - & -5.94 & - & 5.86 & - & 3.95 & - \\
\hline
\end{tabular}

Legend: Ex. $=$ Excellent; Suit $=$ Suitable and $V H=$ Very Hard 
Relationships between chemical quality factors of river water samples

The relationships between chemical quality factors viz., EC, TDS, SAR, SSP, RSC, $\mathrm{H}_{\mathrm{T}}$ and PI were studied. Among the combination, significant positive correlations existed between EC vs TDS, EC vs SAR, EC vs $\mathrm{H}_{\mathrm{T}}$, TDS vs SAR, TDS vs $\mathrm{H}_{\mathrm{T}}$, SAR vs SSP, SAR vs PI and SSP vs PI (Table 5). Negative significant correlations existed among the combinations of EC vs RSC, TDS vs RSC and RSC vs $\mathrm{H}_{\mathrm{T}}$. In rest of the combinations, the relationships between quality criteria were insignificant because their respective calculated $\mathrm{r}$ values were below the tabulated values of $\mathrm{r}$ at both $1 \%$ and $5 \%$ levels of significance.

Table 5. Correlation matrix among chemical quality parameters of river water samples

\begin{tabular}{clllllc}
\hline Parameters & TDS & SAR & SSP & RSC & $\mathrm{H}_{\mathrm{T}}$ & PI \\
\hline EC & $0.998^{* *}$ & $0.641^{* * *}$ & $0.392^{\mathrm{NS}}$ & $-0.584^{* * *}$ & $0.569^{* *}$ & $0.196^{\mathrm{NS}}$ \\
TDS & & $0.628^{* *}$ & $0.371^{\mathrm{NS}}$ & $-0.598^{* *}$ & $0.584^{* *}$ & $0.176^{\mathrm{NS}}$ \\
SAR & & $0.898^{* *}$ & $-0.223^{\mathrm{NS}}$ & $0.207^{\mathrm{NS}}$ & $0.793^{* *}$ \\
SSP & & & $0.228^{\mathrm{NS}}$ & $-0.243^{\mathrm{NS}}$ & $0.974^{* *}$ \\
RSC & & & & $-1.000^{* *}$ & $0.409^{\mathrm{NS}}$ \\
$\mathrm{H}_{\mathrm{T}}$ & & & & & $-0.422^{\mathrm{NS}}$ \\
\hline
\end{tabular}

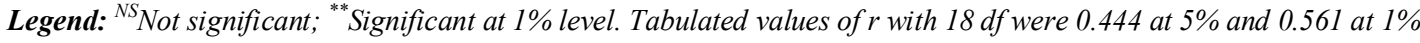
levels of significance, respectively

\section{Conclusions}

Considering all the criteria, it is concluded that among the detected ions under investigation, $\mathrm{Cd}, \mathrm{Cr}$ and $\mathrm{Cl}$ ions were above the permissible limit for long-term irrigation and these ions were treated as water contaminants in river water samples leading to create toxicity of soils and crops. From the present findings, it is noted that the detected ions as water contaminants should be considered for long-term irrigation purpose towards food safety.

\section{References}

Ahmed, M.K.; Shaheen, N.; Islam, M.S.; Al-Mamun, M.H.; Islam, S.; Mohiduzzaman, M. and Bhattacharjee, L. 2015. Dietary intake of trace elements from highly consumed cultured fish and human health risk implications in Bangladesh. Chemosphere 128: 284ї 292.

Ahmed, K.S.; Rahman, A.K.M.L.; Sarkar, M.; Islam, J.B.; Jahan, I.A.; Moniruzzaman, M.; Saha, B. and Bhoumik, N.C. 2016. Assessment on the level of contamination of Turag river at Tongi area in Dhaka. Bangladesh J. Sci. \& Indus. Res. 51: 193 ï 202.

Ali, M.M.; Ali, M.L.; Islam, M.S. and Rahman, M.Z. 2016. Preliminary assessment of heavy metals in water and sediment of Karnaphuli River, Bangladesh. Environ. Nanotechnol, Monitor. \& Manage. 5: 27 ï 35.

APHA (American Public Health Association) 2012. Standard Methods for the Examination of Water and Wastewater. $22^{\text {nd }}$ ed., AWWA and WEF, Washington, USA. pp. 1-39 3-17.

Arefin, M.T.; Rahman, M.M.; Zaman, M.W. and Kim, J.E. 2016. Heavy metal contamination in surface water used for irrigation: Functional assessment of the Turag River in Bangladesh. Appl. Biol. Chem. 59: 83i 90.

Doneen, L.D. 1964. Water Quality for Agriculture. Departmentof Irrigation, University of California, Davis, USA. p. 48.

FAO (Food and Agriculture Organization) 1992. Wastewater Treatment and Use in Agriculture, FAO Irrigation and Drainage Paper 47, Italy. pp. 30̄̄ 32.

FAO (Food and Agriculture Organization) 2011. Irrigation in Southern and Eastern Asia in Figures. Rome, Italy.

Freeze, A.R. and Cherry, J.A. 1979. Groundwater. Prentice Hall Inc., Englewood Cliffs, New Jersey, USA.

Gomez, K.A. and Gomez, A.A. 1984. Statistical Procedures for Agricultural Research. $2^{\text {nd }}$ ed., A Wiley-Interscience Publication, New York, USA. pp. $442 \grave{i} 443$.

Gupta, I.C.; Yaduvanshi, N.P.S. and Gupta, S.K. 2012. Standard Methods for Analysis of Soil Plant and Water. Scientific Publishers, Jodhpur, India. pp. 32ī 36.

Gupta, P.K. 2013. Soil, Plant, Water and Fertilizer Analysis. $2^{\text {nd }}$ ed., Agrobios Jodhpur, India. pp. $254 \bar{i} 263$.

Islam, M.S.; Ahmed, M.K.; Habibullah-Al-Mamun, M.; Islam, K.N.; Ibrahim, M. and Masunaga, S. 2014. Arsenic and lead in foods: A potential threat to human health in Bangladesh. Food Addi. Conta. 31: 1982ï 1992.

Islam, M.S.; Ahmed, M.K.; Raknuzzaman, M.; Habibullah-Al-Mamun, M. and Islam, M.K. 
2015. Heavy metal pollution in surface water and sediment: A preliminary assessment of an urban river in a developing country. Ecol. Indicators 48: $282 \mathrm{ï} 291$.

Islam, M.M.; Azad, A.K.; Ara, M.H.; Rahman, M.; Hassan, N.; Swarnokar, S.C. and Rabeya, I. 2016. Environmental study on a coastal river of Bangladesh with reference to irrigation water quality assessment: A case study on Shailmari River, Khulna. J. Geosci. Environ. Protec. 4: $41 \bar{i} 64$.

Samad, M.A.; Mahmud, Y.; Adhikary, R.K.; Rahman, S.B.M.; Haq, M.S. and Rashid, H. 2015. Chemical profile and heavy metal concentration in water and freshwater species of Rupsha river, Bangladesh. American J. Environ. Protec. 3: 180і̄ 186.

Sawyer, C.N. and McCarty, P.L. 1967. Chemistry for Salinity Engineers. $2^{\text {nd }}$ ed., McGraw Hill, New York, USA. p. 518.

Schwartz, F.W. and Zhang, H. 2012. Fundamentals of Ground Water. Wiley India Pvt. Ltd. New Delhi, India. pp. 374ī 377.
Tandon, H.L.S. (ed.) 2013. Methods of Analysis of Soils, Plants, Waters, Fertilizers and Organic Manures. Fertilizer Development and Consultation Organization, New Delhi, India.

Todd, D.K. and Mays, L.W. 2005. Groundwater Hydrology. $3^{\text {rd }}$ ed., John Wiley and Sons Inc., New York, USA.

Uddin, M.N.; Alam, M.S.; Mobin, M.N. and Miah, M.A. 2014. An assessment of the river water quality parameters: A case of Jamuna river. $J$. Environ. Sci. \& Natur. Resour. 7: $249 \ddot{~} 256$.

Wallender, W.W. and Tanji, K.K. 2011. Agricultural Salinity Assessment and Management. 2nd ed., American Society of Civil Engineers, USA. pp. $98 і ̈ 99$.

Yi, Y.; Yang, Z. and Zhang, S. 2011. Ecological risk assessment of heavy metals in sediment and human health risk assessment of heavy metals in fishes in the middle and lower reaches of the Yangtze river basin. Environ. Pollu. 159: $2575 \mathrm{i} 2585$. 